\title{
DIVORCED MARRIAGES IN THE REPUBLIC OF MACEDONIA REGIONAL ANALYSES OF THE FREQUENCY
}

DOI: http://dx.doi.org/10.18509/GBP.2018.27

UDC: 347.627.2(497.7)"1991/2016"

\author{
Marija Ljakoska \\ Mirjanka Madjevikj \\ Biljana Apostolovska Toshevska \\ University of "Ss Cyril and Methodius" - Skopje, Faculty of natural sciences and mathematics, \\ Institute of geography, Macedonia
}

\begin{abstract}
The influence of the social, economic, political, cultural and other changes and processes that are taking place in the country can be felt in the demogeographic changes that the Republic of Macedonia faces today. This global trend of demogeographic changes, such as lower birth and fertility rates, new conceptions of marriage and family, delayed marriage, new types of communities, changes in the educational level of the population, changes in the economic status, increased number of divorces and other, are also present in the Republic of Macedonia.

The phenomenon of increased number of divorces is especially concerning, because it is becoming an integral part of the society more and more, and it reflects on all the processes of the population, particularly fertility. Despite the new understanding of life and the new types of informal communities, in most countries (even in the most developed), most of the children are still born within the marital union.

This paper elaborates the regional analysis of the trend of divorced marriages in the Republic of Macedonia, the crude divorce rate, the number of divorces per 1,000 inhabitants older than 15 years and the number of divorces per 1,000 marriages in the period from 1991 to 2016. Divorces are also processed according to certain characteristics of the spouses. The purpose of this research is to point out the differences that occur among the regions when it comes to divorce.
\end{abstract}

Keywords: divorces, divorce rate, regional differences, Republic of Macedonia.

\section{INTRODUCTION}

The divorce is a personal and private matter and the decision whether marriage should be ended in divorce or not is the choice of the spouses. By definition, divorce is limited to official unions (be they religious or civil) that can be officially dissolved [3]. The marriage is valid only in conditions when it is concluded before the competent state authorities, and a divorce can only be obtained by the courts responsible for the divorce proceedings [19].

The phenomenon of divortiality is particularly interesting from the demographic point of view because it effects on the whole range of processes related to population, and especially emphasizes the influence on the level of fertility [9]. Despite the new thoughts about life and the new types of informal communities, "It is well known that still today in majority of countries, even in those most developed, the highest extent of births in the population occurs within the marital community." [9]. 
The traditional reasons why divorce was avoided in the past were "for the sake of the children" or to maintain family's "good name". Back then, the kind of marriage "till death do us part", was the dominant model of community, while the divorce was the dominant legal response to the instability of such a community. As community models changed over times and differ more and more, the methods and forms of the outcome of such communities become numerous. As the number of marriages ending in divorce is more frequent, the process of termination of marriage is changing, becomes more flexible and adaptable to the new phenomena. The legal changes might have enabled easy divorce, but other factors, such as changing social mores, greater independence among the younger generation, higher expectations of marriage than in the past, leading to disillusionment when marriages strike trouble, women's greater independence, and increasing temptations for married people to stray in a broader information-filled world have been mentioned as key factors driving the divorce trends [3].

Nowadays, divorce is typically accompanied by a process of family reorganization that includes changes in the parent-child relationship, household routines and living arrangements, socioeconomic circumstances, and social support systems [16].

There are some well-known factors that make married people at higher risk of divorce such as: lower educational level and lower incomes, living together before marriage, premarital pregnancy, religious affiliation, coming from a family of divorced parents, a feeling of insecurity, and more. The spouses who decide to end the marriage with divorce, among the reasons for divorce state: disagreements, infidelity, insufficient commitment, getting married at a very young age, very high expectations of marriage, inequality in the relationships, unpreparedness to marry and domestic violence.

\section{DATA SOURCES AND METHODS OF WORK}

The available census data, as well as the data from the vital statistics, enable monitoring of most of the population structures and processes of the population [14]. Observed through the published statistical data by official statistics, which refer to the Natural Population Change in the Republic of Macedonia, among other data on vital events and processes, (number of births, number of deaths, number of marriages) can be found data on the number of divorces, the duration of the marriage, the number of supported children born during marriage, and the number of divorces according to certain characteristics of the spouses such as age, ethnicity, education and occupation.

A much clearer picture of the frequency of divorces can be obtained by calculating the divorce rate. In order to calculate the divorce rate, it is necessary to know the total number of the population, which is why data from the regular annual publications of the State Statistical Office are used i.e., Population estimates by sex and age by municipality and statistical regions (NUTS 3 -2007) for the respective years and the Statistical Yearbooks, taking in consideration the fact that the last census of the population, households and dwellings in the country was conducted in 2002 [12]. This research could have given even stronger results if we had available data to calculate the specific divorce rates, such as data on the number of persons currently married.

The simplest measure of divorce is the Crude Divorce Rate (CDR), or the number of divorces in a year per 1,000 population at midyear. Note that the Crude Divorce Rate represents the number of divorces, not the number of people getting divorced [5]. The Crude Divorce Rate, just looked at is the most widely used measure of the instability of marriage, but it has the limitation because it expresses the divorce rate with reference to 
the entire population, including children and single adults, rather than concentrating on the population at risk, namely the currently married. When we use a better-focused measure that quantifies divorce per 1,000 married people (which is possible only for countries where up-to-date data on the marital status of the population are available) [4], then we can get much more reliable data. The Crude Divorce Rate is used in regions/countries where the data necessary for calculating more refined rates are not available [17].

Apart from the Crude Divorce Rate, the General Divorce Rate (GDR) is also calculated, i.e., the number of divorces (and not the number of divorced couples) for every 1,000 of the population aged 15 years and above [17]. This rate is calculated by dividing the number of divorces during the reference year/period of time by the estimated population aged 15 years and above in the middle of that year/period of time and multiplying the result by 1,000 [17]. The number of divorces per 1,000 marriages that is also calculated, is an indicator that takes into account both values of nuptiality and divortiality, and thus gives a good insight into the course of the matrimonial transformation process [9].

The census and vital statistics data enable monitoring and comparison of the dynamics in the demographic processes at different territorial units and different time periods. The regional review, analysis refers to the eight statistical regions in the Republic of Macedonia i.e., the NUTS level 3, according the Nomenclature of Territorial Units for Statistics in the Republic of Macedonia [15].

For the purposes of this research are used the analytical-statistical, mathematical, statistical and comparative method. During the analysis and data processing was made a comparative analysis of the results from the research to some previous researches that treat this issue, i.e., relevant demographic studies done so far [12]. Although, in all of the previous geographical population researches in the Republic of Macedonia, the issue of divorce is barely ever elaborated, and all the researches related to divorces are part of some complex geographical research that have the population in their focus.

\section{RESULTS AND DISCUSSION}

The marital status of the population with all its characteristics and specificities is a special challenge for studying by geographers because it reflects at some segments in the demographic development of the country or its separate regions [13].

Despite the fact that we live in a rapidly evolving society that is becoming more educated, more mobile and more interconnected, and besides all of our progress, a steadily increasing divorce rate indicates that we are missing the mark when it comes to the selection of a life partner [18].

Table 1. Divorces in the Republic of Macedonia, 1991-2016

\begin{tabular}{rrr}
\hline Year & Number of divorces & $\begin{array}{r}\text { Index } \\
\mathbf{1 9 9 1}=\mathbf{1 0 0}\end{array}$ \\
\hline $\mathbf{1 9 9 1}$ & 496 & 100 \\
\hline $\mathbf{1 9 9 4}$ & 612 & 123.4 \\
\hline $\mathbf{2 0 0 2}$ & 1,310 & 264.1 \\
\hline $\mathbf{2 0 1 1}$ & 1,753 & 353.4 \\
\hline $\mathbf{2 0 1 6}$ & 1,985 & 400.2 \\
\hline
\end{tabular}




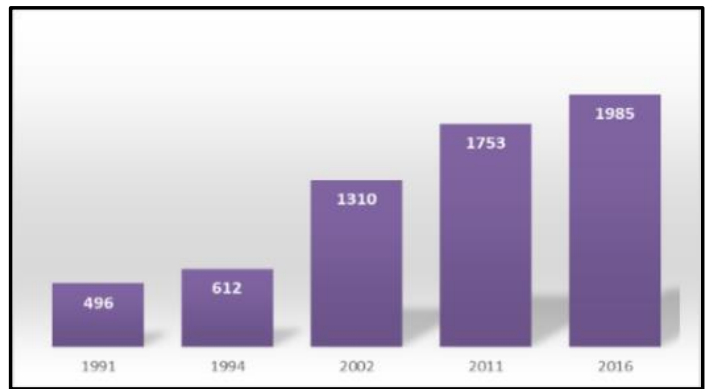

Figure 1. Divorces in the Republic of Macedonia, 1991-2016

The increased number of divorces in the last period is part of this development and is among the most frequent characteristics of family changes in the last decades. The rise in divorce rates in recent decades and the liberalization of divorce law have generally gone hand in hand in most countries [4].

What is the frequency of divorced marriages in the Republic of Macedonia like, can be seen in Table 1 and Figure 1. Namely, the number of divorces increased by 4 times in the analyzed period. The lowest number of divorces was recorded in 1991 and was only slightly higher in 1994. In 2002, the number was more than doubled compared to the previous analyzed year.

The reduced values in 1991 can be linked to the then political instability which, to a certain extent, reduced the chance of independent life, but also with the traditional values which in that period were respected to a greater extent.

The degree of variation is more evident if one looks at the Crude Divorce Rate (divorces per 1,000 inhabitants), but in different regions of the country, they are differences in how long, how fast and how far the divorce rate can reach. However, a more detailed picture of the frequency of divorces can be obtained by calculating the number of divorces per 1,000 inhabitants older than 15 and the number of divorces per 1,000 marriages.

Table 2. Divorce rates in the Republic of Macedonia, 1991-2016

\begin{tabular}{rrrr}
\hline Year & Crude Divorce Rate & General Divorce Rate & Divorces per 1,000 marriages \\
\hline $\mathbf{1 9 9 1}$ & 0.24 & 0.32 & 32.39 \\
\hline $\mathbf{1 9 9 4}$ & 0.31 & 0.42 & 38.89 \\
\hline $\mathbf{2 0 0 2}$ & 0.65 & 0.82 & 90.21 \\
\hline $\mathbf{2 0 1 1}$ & 0.85 & 1.03 & 118.96 \\
\hline $\mathbf{2 0 1 6}$ & 0.96 & 1.15 & 150.39 \\
\hline & & & Source: [22] and author's calculations
\end{tabular}

The Crude Divorce Rate increased from $0.24 \%$ in 1991, to $0.96 \%$ in 2016 or by 4 times. The General Divorce Rate increased from $0.32 \%$ to $1.15 \%$ for the same period, or by almost 4 times. The lowest value of the number of divorces per 1,000 marriages was recorded in 1991 i.e., 32.39\%, while the highest value was recorded in 2016 i.e., $150.39 \%$.

These values point out to the fact that in the Republic of Macedonia the number of marriages is getting smaller, while the number of divorces is continually increasing, which can be seen in the sustainability of marriages. Bearing in mind that the number of marriages has shown a slow but continuous decline, we can assume that even with the same number of divorces, the value of this indicator will continue to grow [9]. The increases in divorce rates have been among the most visible features of the recent decades of family change [8]. 
Given the differences in the distribution of the population and its structure, as well as the differences in the level of development of the regions, there are certainly regional differences in the divorce trend.

In Table 3, we can note that in the period 1991 to 2002, the most significant is the participation of the Polog region, while in 2011, the primacy goes to the Skopje region. This can certainly be related to the massive internal migration, directed mainly towards the Skopje region, which resulted with the largest concentration of the population in this region. The Skopje and Polog region are followed by the Southwest region, while the other regions have smaller participation.

Table 3: Regional differences in the number of divorces, 1991-2016

\begin{tabular}{lrrrrrrrrrr}
\hline & $\mathbf{1 9 9 1}$ & \multicolumn{1}{c}{$\mathbf{1 9 9 4}$} & $\mathbf{2 0 0 2}$ & $\mathbf{2 0 1 1}$ & \multicolumn{2}{c}{$\mathbf{2 0 1 6}$} \\
\hline Regions & Divorces & \multicolumn{1}{c}{ \% } & Divorces & \% & Divorces & \% & Divorces & \% & Divorces & \% \\
\hline East & 39 & 7.8 & 48 & 7.9 & 116 & 8.9 & 128 & 7.3 & 211 & 10.6 \\
\hline Southeast & 49 & 9.9 & 74 & 12.1 & 91 & 6.9 & 176 & 10 & 185 & 9.3 \\
\hline Southwest & 103 & 20.8 & 106 & 17.3 & 78 & 5.9 & 184 & 10.5 & 171 & 8.6 \\
\hline Pelagonia & 72 & 14.5 & 85 & 13.9 & 151 & 11.5 & 158 & 9 & 218 & 11.0 \\
\hline Polog & 112 & 22.6 & 188 & 30.7 & 419 & 32 & 321 & 18.3 & 399 & 20.1 \\
\hline Northeast & 35 & 7 & 9 & 1.5 & 45 & 3.4 & 152 & 8.7 & 89 & 4.5 \\
\hline Skopje & 42 & 8.5 & 76 & 12.4 & 367 & 28 & 550 & 31.4 & 591 & 29.8 \\
\hline Vardar & 44 & 8.9 & 26 & 4.2 & 43 & 3.4 & 84 & 4.8 & 121 & 6.1 \\
\hline Total & 496 & 100 & 612 & 100 & 1310 & 100 & 1753 & 100 & 1985 & 100 \\
\hline & & & & & & & Source: $[21]$ and author's calculations
\end{tabular}

Changes in divorce rates have been linked to the conceptual changes, increasing education and changing labor force participation of women, changing nature of spouse selection, changes in age at marriage, the extent of social support for divorced women, changes in religious and civil laws regulating divorce and changes in life expectancy [3].

Table 4. Regional differences in the divorce rates, 1991-2016

\begin{tabular}{|c|c|c|c|c|c|c|c|c|c|}
\hline & & & 1994 & & & 2002 & & & 2016 \\
\hline Regions & CDR & GDR & $\begin{array}{r}\text { Divorces } \\
\text { per 1,000 } \\
\text { marriages }\end{array}$ & CDR & GDR & $\begin{array}{r}\text { Divorces } \\
\text { per } 1,000 \\
\text { marriages }\end{array}$ & CDR & GDR & $\begin{array}{r}\text { Divorces } \\
\text { per } 1,000 \\
\text { marriages }\end{array}$ \\
\hline East & 0.27 & 0.34 & 38.37 & 0.64 & 0.78 & 105.74 & 1.20 & 1.39 & 227.62 \\
\hline Southeast & 0.44 & 0.58 & 57.50 & 0.53 & 0.66 & 81.39 & 1.07 & 1.27 & 161.85 \\
\hline Southwest & 0.50 & 0.69 & 56.53 & 0.35 & 0.46 & 41.27 & 0.78 & 0.92 & 120.00 \\
\hline Pelagonia & 0.35 & 0.44 & 44.97 & 0.63 & 0.77 & 104.72 & 0.95 & 1.12 & 170.85 \\
\hline Polog & 0.67 & 0.96 & 64.90 & 1.38 & 1.85 & 141.89 & 1.24 & 1.49 & 154.65 \\
\hline Northeast & 0.05 & 0.07 & 6.67 & 0.26 & 0.37 & 42.57 & 0.50 & 0.61 & 77.86 \\
\hline Skopje & 0.14 & 0.18 & 18.07 & 0.63 & 0.79 & 90.93 & 0.95 & 1.16 & 155.90 \\
\hline Vardar & 0.17 & 0.22 & 26.48 & 0.28 & 0.34 & 46.29 & 0.79 & 0.94 & 132.39 \\
\hline Total & 0.31 & 0.42 & 38.89 & 0.65 & 0.82 & 90.21 & 0.96 & 1.15 & 150.39 \\
\hline
\end{tabular}

Divorces by the age of the spouses - In the Figures 2 and 3 can be noted that during the analyzed period, the highest share in the total number of divorces until 2011 has the age groups of 25 to 39 years for the husband, and the age groups of 30 to 44 in 2016, that is, the age groups of 20 to 39 years for the wife until 2011, and then, the age groups of 25 to 39 years. The age group up to 20 years is less likely to participate in the total number of divorces, for both, husband and wife, due to the smaller number of people who are getting married at this age.

Over the past 25 years, the divorce has significantly moved towards the later years of the marital life. Divorce, moving to later stages of marriage can partly be explained by the fact that children become independent and leave the parental home during this period, 
which causes traditional marital union, in which partners are connected by parenting, to lose one of its most important connective elements [10]. This can be confirmed by the fact that more people over the age of 50, among men as well as among women, decide to interrupt the marriage, which according to their age probably lasted for more than 20 years.

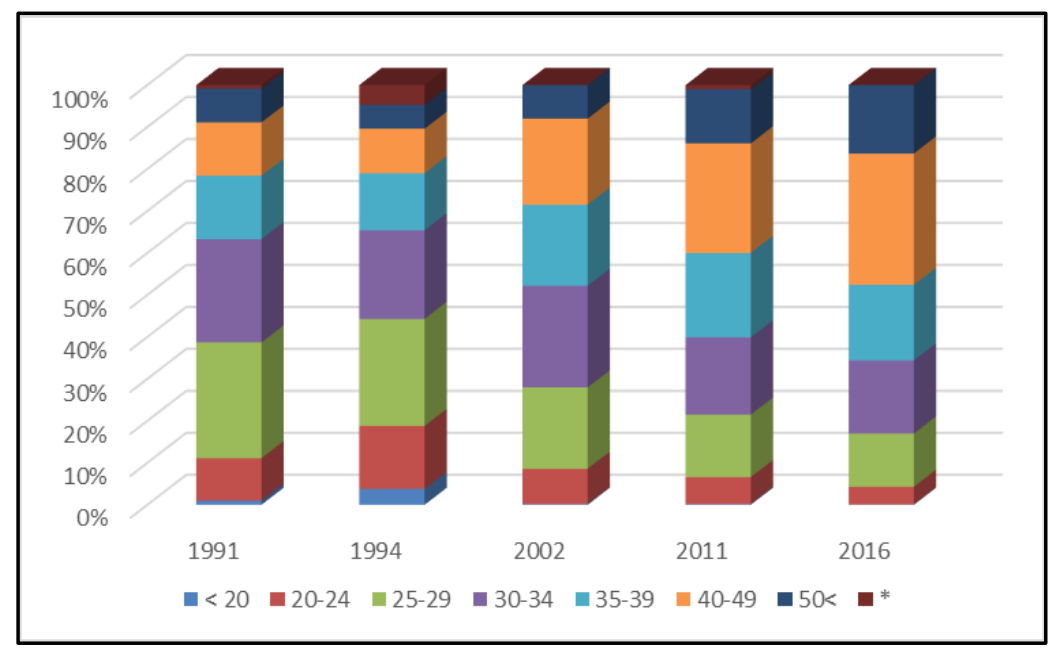

Figure 2. Percentage share of the number of divorces by the age of the husband, 1991-2016

Source: [21] and author's calculations

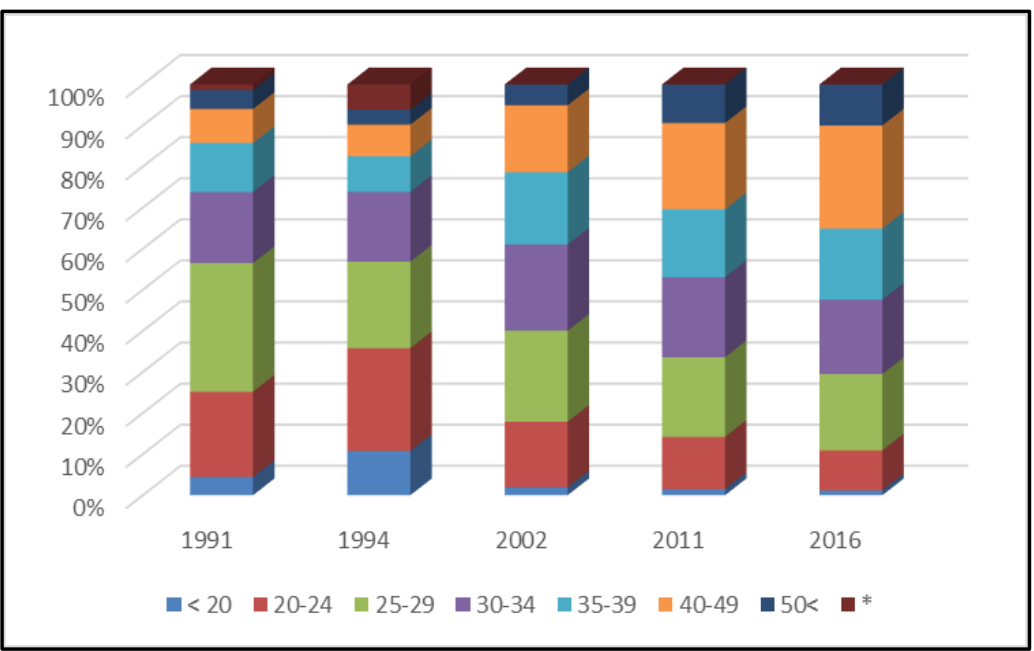

Figure 3. Percentage share of the number of divorces by the age of the wife, 1991-2016

Source: [21] and author's calculations

In Table 5 is presented the developmental tendency of increasing the average age of both husband and wife, especially at the end of the analyzed period.

Table 5: The average age of the spouses when divorced

\begin{tabular}{rrrr}
\hline Year & $\begin{array}{r}\text { The average age of the husband } \\
\text { when divorced }\end{array}$ & $\begin{array}{r}\text { The average age of the wife } \\
\text { when divorced }\end{array}$ & $\begin{array}{r}\text { The average age of the } \\
\text { spouses when divorced }\end{array}$ \\
\hline $\mathbf{1 9 9 1}$ & 31.73 & 29.66 & 30.69 \\
\hline $\mathbf{1 9 9 4}$ & 29.84 & 23.12 & 26.48 \\
\hline $\mathbf{2 0 0 2}$ & 33.72 & 32.27 & 32.99 \\
\hline $\mathbf{2 0 1 1}$ & 34.73 & 33.32 & 34.02 \\
\hline $\mathbf{2 0 1 6}$ & 39.67 & 36.32 & 38.17 \\
\hline & & & Source: Authors calculations using SSORM
\end{tabular}

Source: Authors' calculations using SSORM data 
This points out the fact that although the early age of getting married is listed as one of the main reasons for divorce, the trend of getting married at older ages that we are becoming familiar with, obviously does not change the fact that more and more people decide to end the marriage with divorce anyway.

The increased number of divorced women causes a decrease in fertility, since most of the divorces appear to occur during the woman's fertile period (in 2016, the average age of divorced women was 36.32 years). Women who are older at the time of divorce and have a lack of work experience are facing more difficulties. Very often, after the divorce, women lose the help of the former in-laws, but also, from the mutual friends with the former spouse. They often face an unresolved housing issue, so it is much more difficult for them to decide to get married again or to give birth to a/another child.

When it comes to the number of divorces by the age of the spouses, by regions, we can note that in all of the regions dominant was the age group between 25 to 34 years for the husband, and the age group between 20 and 34 years for the wife in 2002. In 2016, in all of the regions, for both, husband and wife, dominant was the age group between 40 and 49 years.

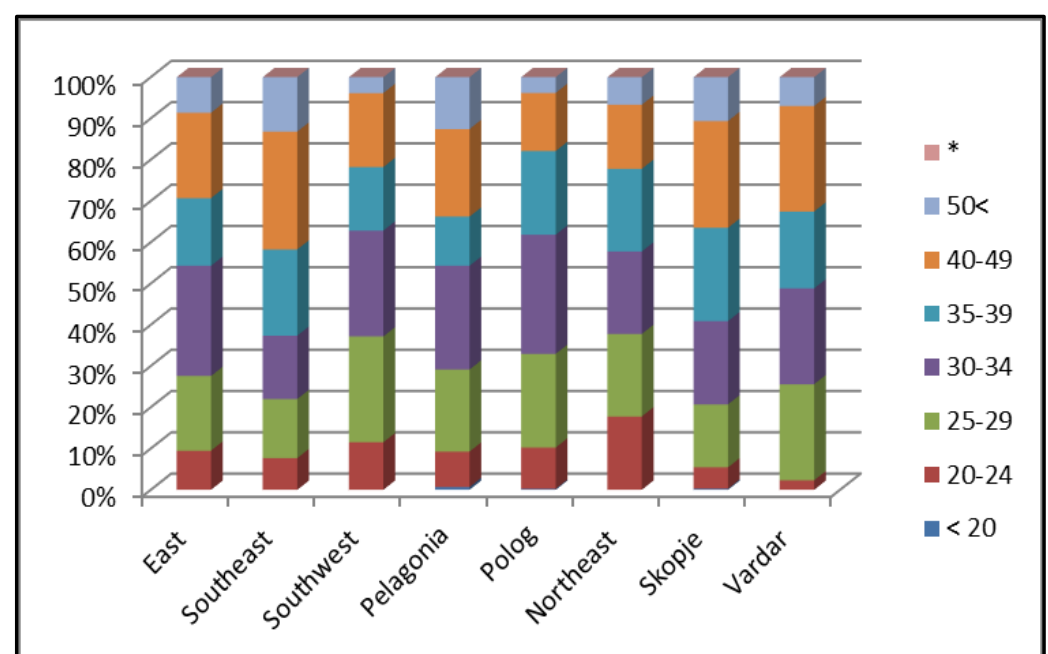

Figure 4. Number of divorces by the age of the husband, by regions, 2002

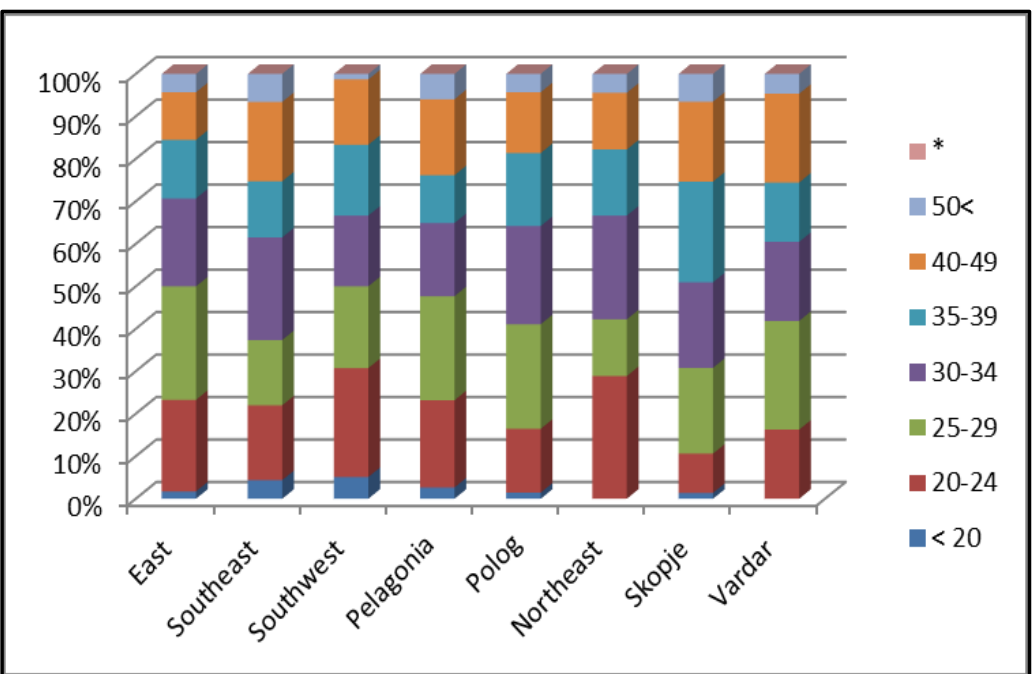

Figure 5. Number of divorces by the age of the wife, by region, 2002 


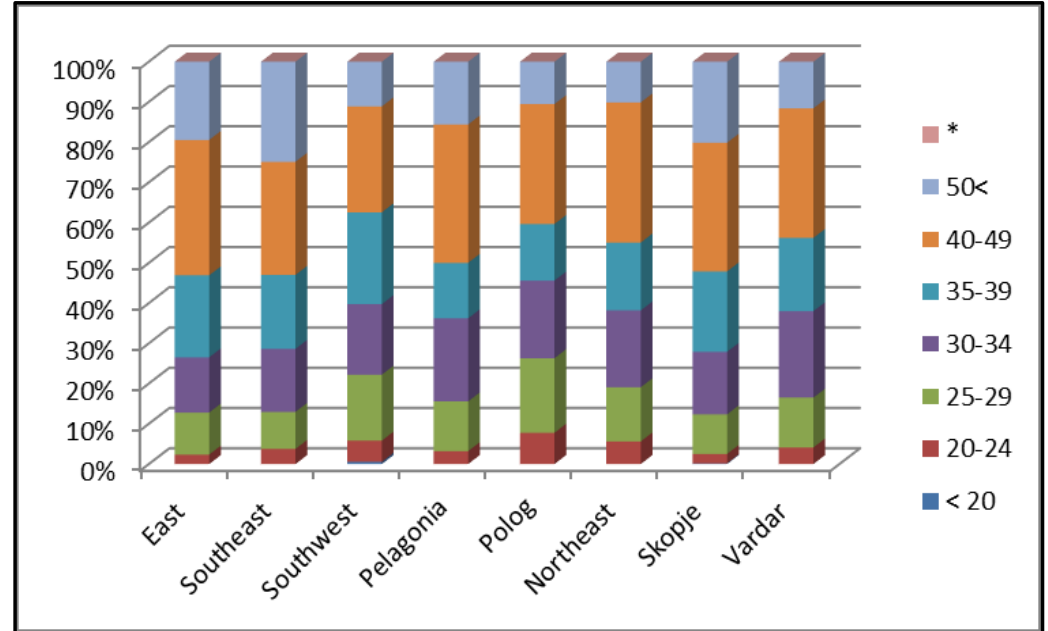

Figure 6. Number of divorces by the age of the husband, by regions, 2016

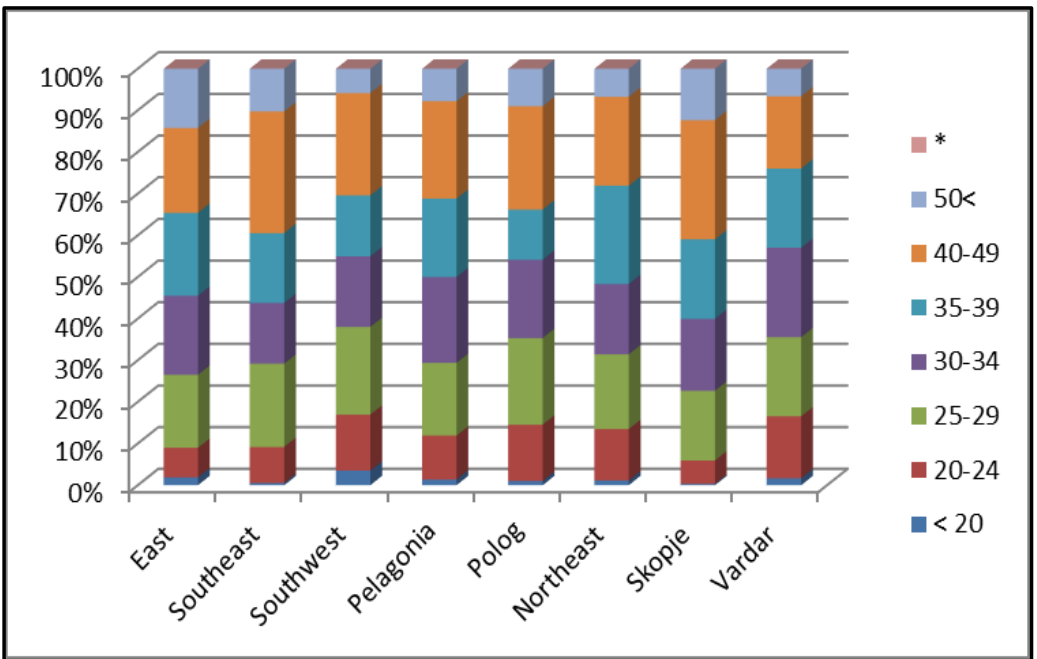

Figure 7. Number of divorces by the age of the wife, by regions, 2016

Source: [21] and author's calculations

Divorces by the duration of marriage - When analyzing data in Table 6, it can be noted that the number of divorces increased in all marriage duration groups. In percentages, the values are reduced for marriages that last from 0 to 9 years, and they increase in marriages that last for longer than 10 years.

These values can be related to the age of the children, because it is more difficult for partners to decide to end the marriage while the children are small, but they can also be related to the new world trends and life expectations that are constantly being imposed and which are slowly but surely accepted.

Table 6. Number of divorces by the duration of the marriage, 1991-2016

\begin{tabular}{rrrrrrrrrr}
\hline Year & Total & $\mathbf{0}$ & $\mathbf{1 - 2}$ & $\mathbf{3 - 4}$ & $\mathbf{5 - 9}$ & $\mathbf{1 0 - 1 4}$ & $\mathbf{1 5 - 1 9}$ & $\mathbf{2 0 - 2 4}$ & $\mathbf{2 5}<$ \\
\hline \multicolumn{7}{r}{} & Percentage share & in the number of divorces by the duration of the marriage & \\
\hline $\mathbf{1 9 9 1}$ & $\mathbf{1 0 0}$ & 7.5 & 26 & 14.7 & 24.2 & 13.8 & 6.8 & 3.2 & 3.8 \\
\hline $\mathbf{1 9 9 4}$ & $\mathbf{1 0 0}$ & 15.3 & 28.8 & 12.7 & 18.9 & 11.6 & 5.7 & 3.9 & 3.1 \\
\hline $\mathbf{2 0 0 2}$ & $\mathbf{1 0 0}$ & 2.6 & 18.9 & 14.3 & 24.8 & 17.5 & 11.8 & 6.1 & 4 \\
\hline $\mathbf{2 0 1 1}$ & $\mathbf{1 0 0}$ & 4.6 & 18.9 & 12.7 & 21.3 & 15.2 & 11.1 & 8.2 & 8 \\
\hline $\mathbf{2 0 1 6}$ & $\mathbf{1 0 0}$ & 4.7 & 13.5 & 12.2 & 22.9 & 14.6 & 12.0 & 9.8 & 10.4 \\
\hline
\end{tabular}

Source: [21] and author's calculations 
Most dominant is the number of divorces that occurred in marriages that lasted between 5 and 9 years, and then in marriages that lasted between 10 and 14 years, and between 1 and 2 years.

The average duration of marriages ending in divorce is constantly increasing by an average of 7.47 years in 1991; 7.63 in 1994; 8.78 in 2002; 9.25 in 2011 and 10.78 in 2016.

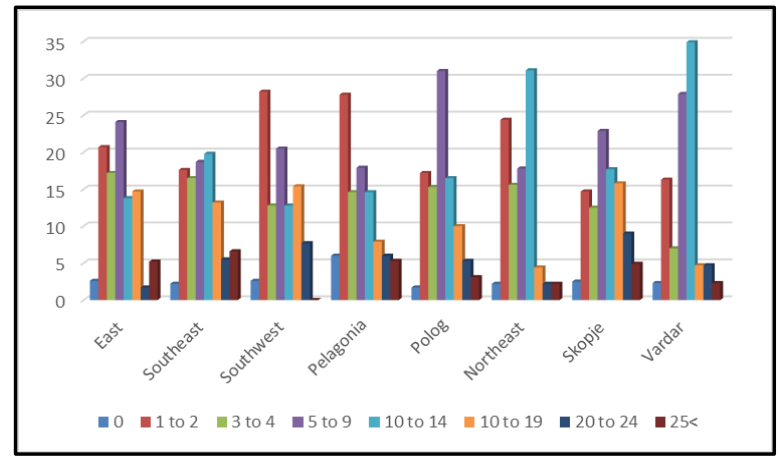

Figure 8. Number of divorces by the duration of the marriage, by regions, 2002

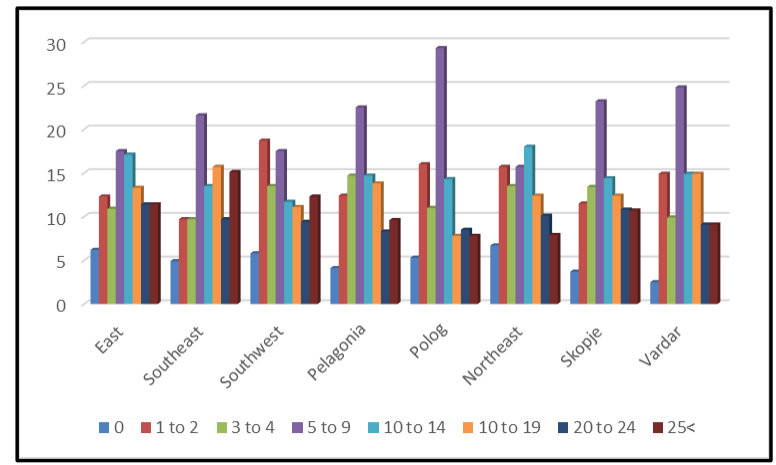

Figure 9. Number of divorces by the duration of the marriage, by regions, 2016

Source: [21] and author's calculations

Divorces by the number of supported children born during a marriage- Many couples who divorce either have no children or have fewer children. Divorced couples with children do not have as many children as married couples at their age that remain married have. It is not clear whether this is because couples who have a stable marriage are more likely to add a second or third child to their family or if a larger number of children inhibits divorce, at least during the children's young years [24], [1]. It is much more likely married couples who do not have children to divorce compared to those who have them, especially if the children are younger.

Table 7. Divorces by the number of supported children born during marriage, 1991-2016

\begin{tabular}{rrrrrrrrr}
\hline \multicolumn{6}{c}{ Number of supported children born during marriage } \\
\hline Year & Total & $\mathbf{0}$ & $\mathbf{1}$ & $\mathbf{2}$ & $\mathbf{3}$ & $\mathbf{4}$ & $\mathbf{5 +}$ \\
\hline $\mathbf{1 9 9 1}$ & 496 & 186 & 136 & 123 & 37 & 11 & 3 \\
\hline $\mathbf{1 9 9 4}$ & 612 & 250 & 130 & 155 & 53 & 18 & 6 \\
\hline $\mathbf{2 0 0 2}$ & 1310 & 604 & 280 & 290 & 107 & 27 & 2 \\
\hline $\mathbf{2 0 1 1}$ & 1753 & 910 & 422 & 327 & 78 & 12 & 4 \\
\hline $\mathbf{2 0 1 6}$ & 1985 & 963 & 463 & 399 & 133 & 23 & 4 \\
\hline
\end{tabular}




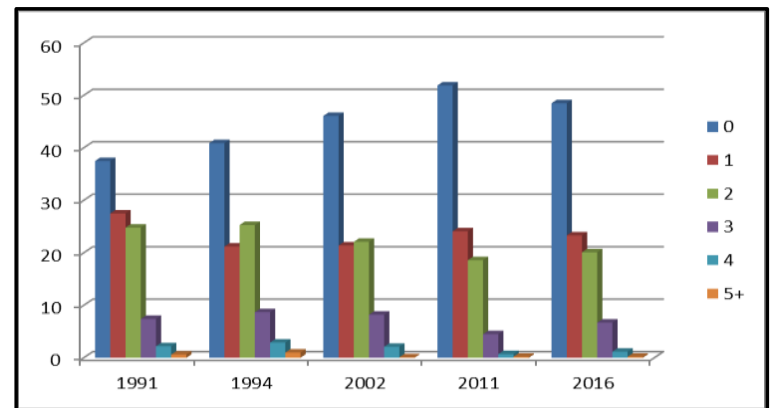

Figure 10. Divorces by the number of supported children born during marriage, 1991-2016, in \% Source: [21] and author's calculations

The analysis of the number of divorces by the number of supported children born during marriage would have given much better results if we had known the structure of families in the country by the number of supported children. These analyzes should be considered for the purpose of creating policies to support single-parent families, which are becoming more numerous by the increasing number of divorces.

In the Republic of Macedonia, most of the divorced couples do not have children. They are followed by the number of divorced couples with one or two children. The situation is the same in all of the regions.

Table 8. Number of divorces by the number of supported children born during marriage, by regions, 2002-2016

\begin{tabular}{|c|c|c|c|c|c|c|c|}
\hline Regions & Total & $\mathbf{0}$ & 1 & 2 & 3 & 4 & $5+$ \\
\hline \multicolumn{8}{|c|}{ Percentage share in the number of divorces by the duration of the marriage, 2002} \\
\hline East & 100 & 37.1 & 28.4 & 25.9 & 6.9 & 1.7 & 0.0 \\
\hline Southeast & 100 & 46.2 & 20.9 & 25.3 & 6.6 & 1.1 & 0.0 \\
\hline Southwest & 100 & 51.3 & 15.4 & 19.2 & 9.0 & 5.1 & 0.0 \\
\hline Pelagonia & 100 & 54.3 & 24.5 & 18.5 & 2.0 & 0.0 & 0.7 \\
\hline Polog & 100 & 48.0 & 13.6 & 26.3 & 9.8 & 2.1 & 0.2 \\
\hline Northeast & 100 & 37.8 & 20.0 & 20.0 & 11.1 & 11.1 & 0.0 \\
\hline Skopje & 100 & 43.6 & 28.3 & 18.3 & 8.4 & 1.4 & 0.0 \\
\hline Vardar & 100 & 44.2 & 20.9 & 18.6 & 14.0 & 2.3 & 0.0 \\
\hline Total & 100 & 46.1 & 21.4 & 22.1 & 8.2 & 2.1 & 0.2 \\
\hline \multicolumn{8}{|c|}{ Percentage share in the number of divorces by the duration of the marriage, 2016} \\
\hline East & 100 & 46.9 & 24.2 & 21.8 & 7.1 & 0.0 & 0.0 \\
\hline Southeast & 100 & 44.3 & 23.2 & 22.7 & 8.6 & 1.1 & 0.0 \\
\hline Southwest & 100 & 54.4 & 24.0 & 14.0 & 6.4 & 1.2 & 0.0 \\
\hline Pelagonia & 100 & 52.8 & 24.8 & 16.1 & 5.0 & 1.4 & 0.0 \\
\hline Polog & 100 & 57.6 & 14.5 & 19.3 & 6.8 & 1.8 & 0.0 \\
\hline Northeast & 100 & 43.8 & 21.3 & 25.8 & 9.0 & 0.0 & 0.0 \\
\hline Skopje & 100 & 42.8 & 29.4 & 21.0 & 5.2 & 1.4 & 0.2 \\
\hline Vardar & 100 & 43.0 & 19.0 & 23.1 & 11.6 & 0.8 & 2.5 \\
\hline Total & 100 & 48.5 & 23.3 & 20.1 & 6.7 & 1.2 & 0.2 \\
\hline
\end{tabular}

The place we choose to live affects every aspect of our being. It can determine the income we earn, the people we meet, the friends we make, the partners we choose, and the options available to our children and families [6], [18]. It also affects the acquired attitudes about life, habits, and customs.

The results of the analysis by region shows that there are differences in the number of divorces and the geographical position which could serve as a basis for new, additional research on several indicators in order to determine the influence of culture, tradition, 
customs and habits in these regions. "Cultural and demographic differences in marriage also may play a role. Early and arranged marriages, which are risk factors for divorce, appear to be less common" [25].

The changes arise from the changes in the total number of population and its ethnic structure, the spatial distribution of the population, the concentration of nationalities in certain regions, or their dispersion to a larger area, migration, social relations, political events in the state and the immediate surroundings, interethnic relations, general tendencies in getting married, educational and cultural achievements of nationalities, the perceptions of marriage and divorce, and so on. It is clear, however, that modernization will lead to a further increase in divorce rates in most parts of the country [25].

\section{CONCLUSION}

Marriage and divorce behaviors are of interest to both demographers and the general public as they shed light on family formation, family composition and fertility [2]. Divorce has become a part of the family institution and a realistic possibility which spouses need to take into consideration when marrying [8].

The complex of: social, economic, political, security and other circumstances and conditions caused significant changes and left a strong mark in the past period. The legal changes make it easier to end a marriage with divorce compared to the past. But there are other factors, such as changing the habits, greater independence of the younger generation, higher expectations of marriage compared to the past (leading to disappointment when the marriage will face problems), greater independence of women and more. These are key factors that determine the trend of divorces.

In the Republic of Macedonia, the number of divorces increased significantly during the analyzed period, i.e. for more than 4 times. The Crude Divorce Rate also increased by 4 times, or from $0.24 \%$ in 1991 , to $0.96 \%$ in 2016.

The number of divorces was the highest in the Polog region until 2016, when the highest value was recorded in the Skopje region. This change occurred due to the highest percentage share of population living in this region, which is almost one third of the total population in the country. The divorce rates were also highest in the Polog region. The development tendency of increasing the average age of both husband and wife is recorded in all regions. However, despite this rising trend in the number of marriages, the Republic of Macedonia has the lowest values in the divorce rates compared to the countries in the region, (in 2015, the CDR was 1.2 in Slovenia; 1.3 in Serbia and Albania; 1.4 in Croatia; and 1.5 in Bulgaria) [26].

The regional differences in socioeconomic status and background might partially account for the regional difference in divorce, but as Kephart (1981) stated "all of the reasons for the regional divorce differentials are not known. If they were, we would be in a much better position to understand the problem of divorce causation [11], [7].

The increased interest of spouses in a divorce in modern societies arises the need to study this both, demographic and sociological, psychological and legal phenomena, as well as the consequences which it has on society, individuals and processes in the population [9]. The research points to the need for additional and more detailed analyses and literature research, analysis of the marriage and divorce rates in terms of demographic variables (such as the age and population marital structure), social variables (such as education and tradition) and economic variables (such as income and labor force participation), as well as defining the main causes of divorce, the regional differences in the number of divorces 
and, of course, their impact on all family members. The results from the research indicate to the need to create a population policy in line with the trend of population development and its marital structure. Also, seminars and conferences must be organized to present the findings of specialized studies and research in the field of marriage and divorce, to be attended by competent representatives from related government agencies, consultancies, universities, and research centers, various institutions of the civil society and individuals interested in family affairs [17].

\section{REFERENCES}

[1] Ambert A. M. Contemporary family trends, Facts, Causes \& Consequences. The Vanier Institute of the Family, 3rd Edition, Canada, 2009.

[2] Census and Statistics Department, Hong Kong Special Administrative Region, Hong Kong Monthly Digest of Statistics 1991-2013, Hong Kong Monthly Digest of Statistics, China, 2015.

[3] Dommaraju P. \& Jones G. Divorce Trends in Asia, Asian Journal of Social Science, Singapore, vol. 39. pp 725-750, 2011.

[4] Fahey T. Divorce trends and patterns in the Western world: a socio-legal overview, UCD Geary institute discussion paper series, Ireland, 2013.

http://www.ucd.ie/geary/static/publications/workingpapers/gearywp201320.pdf

[5] Faust K. The methods and materials of demography, Elsevier academic press, Second edition, Chapter 9, Marriage, divorce, and family groups, USA, pp 191-210, 2004.

[6] Florida R. Who's Your City? How the Creative Economy Is Making Where to Live the Most Important Decision of Your Life. New York: Basic Books. USA, 2008.

[7] Glenn N. D. \& Shelton A. B. Regional Differences in Divorce in the United States, Journal of marriage and the family, pp 641-652, 1985.

[8] Härkönen J. Divorce: Trends, Patterns, Causes, Consequences, Stockholm Research Reports in Demography, Sweden, vol. 7, 2013.

[9] Ivković M. The frequency of divorced marriages in Serbia (1947-2010), Collection of Papers - Faculty of Geography, University of Belgrade, Serbia, vol. 59, pp 65-76, 2011.

[10] Ivković M., Todorić J. \& Mucić M. Marital behavior of the elderly population in Serbia, Proceedings for Social Science by Matice Srpske, Human Resources and Regional Development, Novi Sad, Serbia, pp 677-685, 2014.

[11] Kephart W. M. The Family, Society, and the Individual, 5th Edition, Boston: Houghton Mifflin, USA, 1981.

[12] Ljakoska M. \& Madjevikj M. Trends and leading causes of death in the Republic of Macedonia (regional review), International Scientific Conference GEOBALCANICA 2017, Macedonia, 2017, pp 199-206.

[13] Madjevikj M. Ethnic homogeneous marriages in the Republic of Macedonia, Herald of Socioeconomic Geography, Macedonia, vol. 3, pp 29-35, 2009.

[14] Madjevikj M. The structure of the population of the Republic of Macedonia according to the marital status, Proceedings from the third congress of the geographers in the Republic of Macedonia, Macedonia, 2005, pp 237-243.

[15] Madjevikj M., Apostolovska Toshevska B. \& Ljakoska M. Regional differences in the population natural increase in the Republic of Macedonia, Journal of the Geographical Institute "Jovan Cvijic" - SASA, Serbia, vol. 66 (3), pp 417-431, 2016.

[16] Morrison D. R., Coiro M. J. \& Blumenthaf C. Marital disruption, conflict, and the well-being of children, Annual meeting of the population association of America, USA, pp 1-22, 1994. 
[17] Population Reference Bureau. Marriage and Divorce Rates in the Emirate of Abu Dhabi. Social Studies Series, vol. 1, United Arab Emirates, 2011.

[18] Scott H. A., Berger P. D. \& Weinberg B. D. Determinants of the U.S. Divorce Rate: The Impact of Geography and Demography, International Journal of Humanities and Social Science, USA, vol. 1 No. 19, 2011.

[19] Sentić M. Characteristics of the marriage and divorce development in Yugoslavia, Population, Serbia, vol. II No. 4, pp. 329-338.

[20] SSORM, Census of population, households and dwellings in the Republic of Macedonia, 2002, Book I, Skopje, 2004.

[21] SSORM, Natural Population Change, 1991-2016, Skopje, Republic of Macedonia.

[22] SSORM, Statistical Yearbook, 1991-2016, Skopje, Republic of Macedonia.

[23] SSORM, The 1994 census of population, households, dwellings and agricultural holdings in the Republic of Macedonia, Book XIII, Skopje, 1997.

[24] Vanderschelden M. Les ruptures d'unions: plus frequentes, mais pas plus precoces. Insee, 1107, France, 2006. file:///D:/Downloads/Ip1107.pdf.

[25] Zeng Y. \& Wu D. Regional Analysis of Divorce in China since 1980, Demography, vol. 37, No 2, pp 215-219, 2000.

[26] http://ec.europa.eu/eurostat/data/database (last visited on 25.02.2018)

[27] www.stat.gov.mk (last visited on 25.02.2018) 